\title{
Effect of Acetic Acid on Denitrification and Dephosphatation Process Efficiencies in Sequencing Batch Biofilm Reactor
}

\author{
Artur Mielcarek ${ }^{1 *}$, Joanna Rodziewicz ${ }^{1}$, Wojciech Janczukowicz ${ }^{1}$, Kamil Bryszewski ${ }^{1}$ \\ 1 Department of Environment Engineering, Faculty of Environmental Sciences, University of Warmia and \\ Mazury in Olsztyn, ul. Warszawska 117a, Olsztyn 10-719, Poland \\ Corresponding author's e-mail: artur.mielcarek@uwm.edu.pl
}

\begin{abstract}
This study investigates the feasibility of using an organic substrate in the form of acetic acid to enable wastewater denitrification in a Sequencing Batch Biofilm Reactor (SBBR). The impact of nitrates presence on the yield of biological dephosphatation was determined as well. The experiment included 296 cycles and was divided into 4 series differing in the load of nitrates. The N:(C and P) ratios were: 7:(140 and 7); 35:(140 and 7); 70:(140 and 7) and 140:(140 and 7). The hydraulic retention time in the reactor was $12 \mathrm{~h}$ ( $6 \mathrm{~h}$ of mixing - dissolved oxygen concentration below 0.1 and $6 \mathrm{~h}$ of aeration - concentration of dissolved oxygen $\left.3.0 \pm 0.8 \mathrm{mgO}_{2} \cdot \mathrm{dm}^{-3}\right)$. The study demonstrated that the 30-day adaptation period (60 cycles) was sufficient for the development of a stable biofilm. The $\mathrm{C}: \mathrm{N}$ ratio of 2 ensured the total nitrogen concentration in the effluent below $1 \mathrm{mgN} \cdot \mathrm{dm}^{-3}$. The mean efficiency of biological dephosphatation reached $7.0,17.4,18.7$, and $30.3 \%$ in series $1-4$, respectively. In the case of series 2 and 3, no significant differences were demonstrated in the total phosphorus concentration in the effluent. In the other series, the differences turned out to be significant.
\end{abstract}

Keywords: Sequencing Batch Biofilm Reactor, denitrification, dephosphatation, acetic acid

\section{INTRODUCTION}

Unlike the activated sludge, the biofilm is less susceptible to the changes of such technological parameters as: contaminants load, volume of inflowing wastewater or presence of toxic substances in wastewater. This is due to high quantities of extracellular polymeric substances (EPS) which constitute a buffer to microorganisms [Boltz et al. 2017, Nicolella et al. 2000b]. As a result of long period of biomass retention in a reactor, the biofilm is characterized by a higher degree of mineralization and, thus, by a lower volume of excess biomass discharged from the reactor. It is important considering the necessity of excess biomass management [Helness and Odegaard 2001]. For this reason, the reactors with a biofilm are widely applied in small wastewater treatment plants where they often work in the maintenance-free mode. Such reactors ensure a high efficiency of organic matter removal and nitrification. Howev- er, denitrification and dephosphatation of wastewater are often curbed by the concentration of the available organic compounds. Nevertheless, biofilm reactors have a vast potential for simultaneous and effective removal of nitrogen and phosphorus compounds from wastewater as a result of the likely co-occurrence of aerobic, anoxic and anaerobic conditions in one reactor [Boltz et al. 2012, Gieseke et al. 2002].

The problem of organic compounds deficit may be solved through the use of an external source of organic carbon. A substrate fed to the reactor should, however, be characterized by a high efficiency of utilization and of aiding biological processes. In addition, it should be safe to users considering, e.g., its dosage in poorly controlled installations or the installations with possible access of unauthorized persons [Janczukowicz and Rodziewicz 2013, Mielcarek et al. 2013].

In this experiment, we investigated the feasibility of using an external source of organic car- 
bon in a sequencing batch reactor with a biofilm (SBBR). The demand of the biofilm bacteria for an organic substrate in the form of acetic acid to enable wastewater denitrification as well as the effect of nitrates presence of the yield of biological dephosphatation, were determined.

\section{METHODS}

The experiment was carried out in a Sequencing Batch Biofilm Reactor (SBBR). The volume of reactor was $5 \mathrm{~L}$. The SBBR filling was a set of 8 disks made of acidproof steel with diameter of $0.1 \mathrm{~m}$ and thickness of $1 \cdot 10^{-3} \mathrm{~m}$ each. The disks surface to reactor active volume ratio was $25 \mathrm{~m}^{2} / \mathrm{m}^{3}$. The SBBR construction enabled only the formation of biomass in the form of a biofilm coating the disks, discharge of the whole volume of wastewater with excess biomass, as well as periodical aeration and stirring of wastewater. The disks were rotating with the speed of $60 \mathrm{rpm}$.

\section{Synthetic wastewater and organic carbon source}

The characteristics of the synthetic wastewater used in the experiment were similar to the ones of the nitrification process effluent (Table 1). The experiment was divided into 4 series differing in the $\mathrm{N}:(\mathrm{C}$ and $\mathrm{P})$ ratio. The organic matter load was constant and reached $11.2 \mathrm{gC} \cdot \mathrm{m}^{-2} \cdot \mathrm{d}^{-1}$, which ensured a stable volume of biomass in the reactor throughout the experiment. A solution of acetic acid was used as the substrate and its dose was adopted after an overview of literature data [Mielcarek et al. 2016, 2017; Park et al. 2008]. The initial concentration of total organic carbon (TOC) in wastewater was assumed at 140 $\mathrm{mgC} \cdot \mathrm{dm}^{-3}$. The load of nitrogen compounds was increased in the successive experimental series.

Table 1. Physicochemical characteristic of synthetic wastewater

\begin{tabular}{|l|c|c|}
\hline \multicolumn{1}{|c|}{ Parameter } & Unit & Value \\
\hline Temperature & ${ }^{0} \mathrm{C}$ & $22 \pm 2$ \\
\hline Redox potential & $\mathrm{mV}$ & $180 \pm 10$ \\
\hline $\mathrm{pH}$ & - & $7.70 \pm 0.1$ \\
\hline $\begin{array}{l}\text { Total organic carbon } \\
(\text { TOC) }\end{array}$ & $\mathrm{mgC} \cdot \mathrm{dm}^{-3}$ & $<1$ \\
\hline Total nitrogen (TN) & $\mathrm{mgN} \cdot \mathrm{dm}^{-3}$ & $7.0-140.0$ \\
\hline Nitrate & $\mathrm{mgN} \cdot \mathrm{dm}^{-3}$ & $7.0-140.0$ \\
\hline Total phosphorus (TP) & $\mathrm{mgP} \cdot \mathrm{dm}^{-3}$ & 7,00 \\
\hline
\end{tabular}

The N:(C and $\mathrm{P})$ ratios were : 7:(140 and 7) in cycles $1-116$ (series 1$) ; 35:(140$ and 7$)$ in cycles 117-176 (series 2); 70:(140 and 7) in cycles 177-236 (series 3) and 140:(140 and 7) in cycles 237-296 (series 4). It corresponded to nitrogen load from 0.56 to $1.12 \mathrm{gN} \cdot \mathrm{m}^{-2} \cdot \mathrm{d}^{-1}$.

The activated sludge from the "Łyna" Municipal Sewage Treatment Plant in Olsztyn constituted the inoculum. The hydraulic retention time in the reactor was $12 \mathrm{~h}$ ( $6 \mathrm{~h}$ of mixing - dissolved oxygen concentration below $0.1 \mathrm{mgO}_{2} \cdot \mathrm{dm}^{-3}$ and $6 \mathrm{~h}$ of aeration - concentration of dissolved oxygen $\left.3.0 \pm 0.8 \mathrm{mgO}_{2} \cdot \mathrm{dm}^{-3}\right)$. The lack of a sedimentation phase resulted from the replacement of the whole treated wastewater together with the exfoliated biofilm. The exact experiment was preceded by 30-day period of reactors adaptation, when the technological parameters were the same as in series 1 . The reactor was operated at a temperature of $20-24^{\circ} \mathrm{C}$. Each time, $5 \mathrm{dm}^{3}$ of wastewater were fed to bioreactors. The samples were collected at the end of the cycle and filtered through a medium filter. The analyses were carried out at the laboratory of the Department of Environmental Engineering, University of Warmia and Mazury in Olsztyn.

The study involved measurements of the $\mathrm{pH}$ value and temperature using $\mathrm{CP}-105$ waterproof pH-meter (elmetron, Poland); redox potential using pH211 Microprocessor (Hanna Instruments, Spain); dissolved oxygen using Oxi 330i/set (WTW, Germany); total organic carbon with the "oxidative combustion-analysis in infrared" method and total nitrogen with the "oxidative combustion-chemiluminescence" method using TOC-L with TNM-L device analyzer (Shimadzu Corporation, Japan); total phosphorus was determined using UV-VIS 5000 DR spectrophotometer (HACH Lange, Germany) with the HACH Lange LCK 348-350 method. The biomass growth during one cycle was determined by filtration of the whole volume of the treated wastewater through a medium filter, followed by the dry mass retained on the filter, according to PN-EN 872:2007 standard.

The statistical analysis of results was conducted using the Statistica 12computer software. Before selecting an appropriate statistical test, normal distribution of the variable and homogeneity of the variance were checked in each compared group. Normality of distribution was verified with the Shapiro-Wilk W test, while homogeneity was verified with the Levene's test. When the results 
obtained showed normal distribution and homogenous variance, the analysis of variance ANOVA and multiple comparison test, the so-called posthoc HSD Tukey's test, were employed. When the variables did not meet the above-mentioned criteria, an alternative non-parametric KruskalWallis test was used. The level of significance was adopted at 0.05 .

\section{RESULTS AND DISCUSSION}

The time needed for biofilm formation and adaptation may vary depending on the technical and technological solutions. In a study conducted by Mielcarek et al. [2016, 2017], the time needed to reach a stable biofilm in the SBBR type reactor working only under anaerobic conditions was ca. 43 days with waste beer used as an organic substrate and ca. 48 days with citric acid used instead. In the experiment carried out by CydzikKwiatkowska et al. [2016] involving pelletized aerobic sludge, the time needed for SBR reactor adaptation was equal to 70 eight-hour cycles (ca. 24 days). Afterwards, the parameters of the treated wastewater did not change by more than $10 \%$ between cycles [Kwiatkowska et al. 2016]. Similar values were reported by Mieczkowski et al. [2016]. In turn, Guo et al. [2005] found ca. 30-day period of a biofilm reactor adaptation as sufficient to achieve its stable work after modification of the technological parameters (organic matter load fed to the reactor). The adaptation period caused by the dosage of an external source of organic carbon in the form of wastewater from a distillery, brewery and fish marinating reached 2 weeks for activated sludge at the full technical scale [Swinarski et al 2009]. Similarly, stable conditions were achieved after 15 days for the SBR type reactor fed with acetate and used for the treatment of wastewater with a high concentration of nitrates $\left(1000 \mathrm{mgN} \cdot \mathrm{L}^{-1}\right)$ [Jena et al. 2016].

In the conducted study, the 30-day adaptation period ( 60 cycles) was sufficient for the development of a stable biofilm. The biofilm thickness ranged from ca. 1 to $20 \mathrm{~mm}$ and enabled an effective consumption of the organic substrate. The concentration of organic carbon in the effluent accounted for $3.5 \pm 0.6,2.8 \pm 1.2,2.7 \pm 1.5$, and $2.7 \pm 1.5 \mathrm{mgC} \cdot \mathrm{dm}^{-3}$ in series $1,2,3$ and 4 , respectively (with organic substrate concentration at the beginning of the cycle reaching $-140 \mathrm{mgC} \cdot \mathrm{dm}^{-3}$ ). These values were not statistically significantly different (Fig. 1). The high efficiency of the organic substrate uptake corresponded to a high efficiency of denitrification. In series $1-3$, when the $\mathrm{C}: \mathrm{N}$ ratio ranged from 2 (series 3 ) to 20 (series 1 ), the total nitrogen concentration in the effluent reached $0.63 \pm 0.10,0.80 \pm 0.31$ and $0.62 \pm 0.22$ $\mathrm{mgN} \cdot \mathrm{dm}^{-3}$ in series 1,2 and 3 , respectively. These values were not statistically significantly different. In series 4 (with $\mathrm{C}: \mathrm{N}$ ratio of 1), the mean concentration of $\mathrm{TN}$ in the effluent increased significantly and reached $83.29 \pm 3.62 \mathrm{mgN} \cdot \mathrm{dm}^{-3}$. The use of acetic acid and alkalinity increase induced by denitrification also contributed to the $\mathrm{pH}$ increase from $\mathrm{pH} 5.9$ in the treated wastewater to the $\mathrm{pH} 8.23-8.56$ in the effluent. The occurrence of anoxic-anaerobic conditions may stimulate the denitrifying activity of PAOs bacteria [Zeng et al. 2003]. Oxygen may appear in the biofilm even at a depth of ca. 100-150 $\mu \mathrm{m}$ [Nerenberg 2016]. For this reason, three layers of biofilm may be distinguished under varying conditions of aeration and stirring, i.e. a layer with aerobic-anoxic-anaerobic conditions, a layer with anoxic-anaerobic conditions, and an anaerobic layer where mainly biofilm degradation proceeds. At the same morphological parameters of the biofilm, the depth of nitrates penetration depends on their concentration in the wastewater being treated [Nicolella 2000a]. This was the likely reason of a significant increase in the dephosphatation efficiency along with increased concentration of nitrates in wastewater. It reached 7.0, 17.4, 18.7, and $30.3 \%$ in series $1-4$, respectively. This corresponded with the mean concentration of total phosphorus from 6.51 to $4.88 \mathrm{mgP} \cdot \mathrm{dm}^{-3}$. In the case of series 2 and 3 , no significant differences were demonstrated in the total phosphorus concentration in the effluent. In other series, the differences turned out to be significant (Fig. 1). The increased dephosphatation activity of microorganisms in the successive series confirms the fact that no statistically significant differences were found in the volume of biomass discharged from the reactor (the percentage content of phosphorus in biofilm dry matter had to increase). The volume of biomass discharged in the subsequent series was: $22 \pm 11$; $21 \pm 12 ; 20 \pm 7$, and $20 \pm 6 \mathrm{mg} \cdot \mathrm{dm}^{-3}$ (Fig. 1).

In addition, the increasing load of nitrates fed to the reactor contributed to the changes in the redox conditions in the reactor. In series 1 , with $\mathrm{N}:(\mathrm{C}$ and $\mathrm{P})$ at 7:(140 and 7), the redox potential determined at the end of the stirring stage reached (-) $136.8 \pm 24.1 \mathrm{mV}$. The $6 \mathrm{~h}$ aeration stage caused the redox potential to increase to the val- 

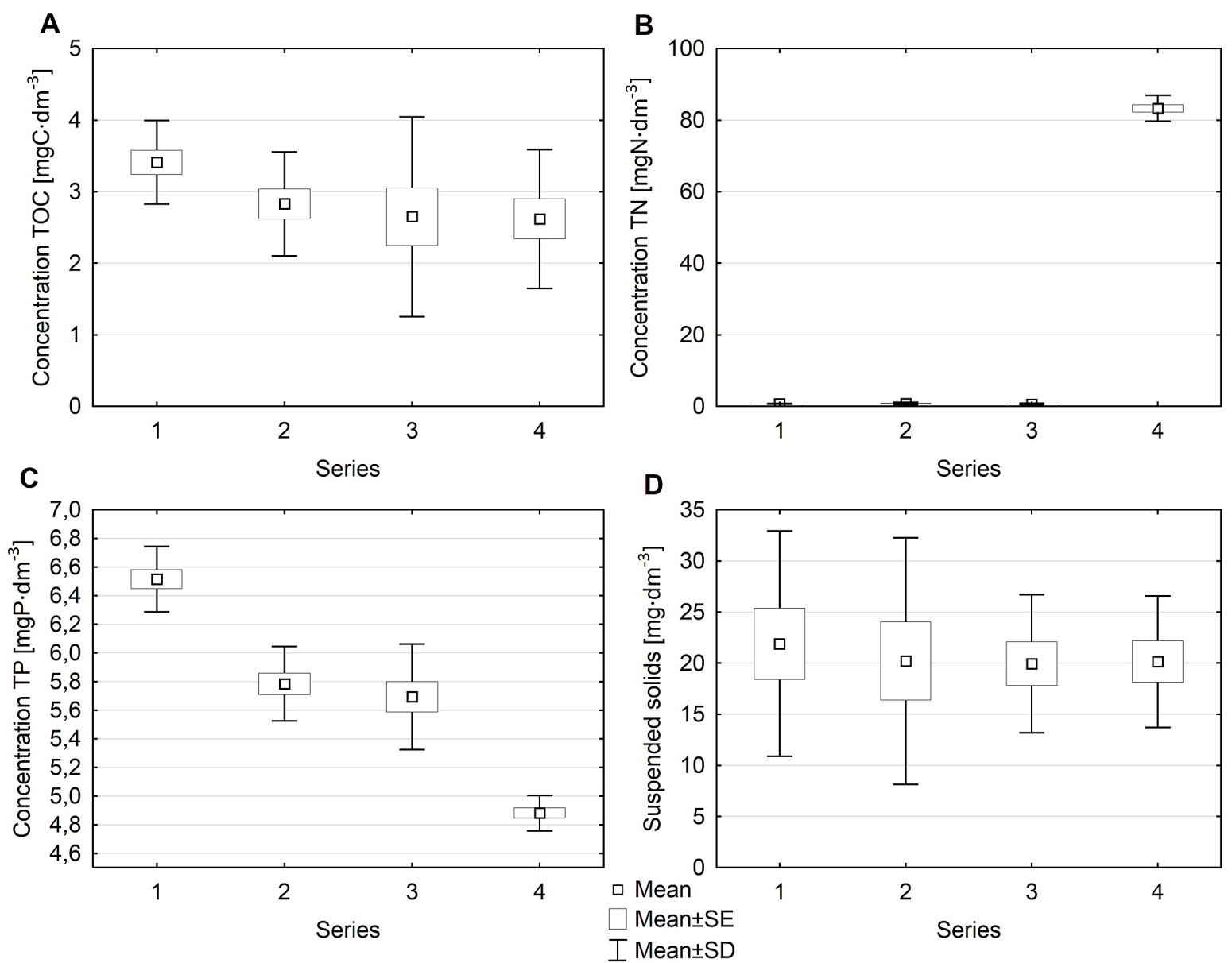

Figure 1. Physicochemical parameters in the effluent from SBBR (A - concentration of total organic carbon; $\mathrm{B}$ - concentration of total nitrogen; $\mathrm{C}$ - concentration of total phosphorus; D - suspended solids)

ue of $53.0 \pm 11.5 \mathrm{mV}$. In series 4 with the highest $\mathrm{N}:(\mathrm{C}$ and $\mathrm{P})$ ratio, the redox potential accounted for $205.8 \pm 12.6$ and $252.5 \pm 12.7 \mathrm{mV}$ at the end of stirring and aeration stages, respectively. This offered beneficial conditions for enhanced intracellular accumulation of polyphosphates already at the stirring stage of the subsequent series.

\section{CONCLUSION}

The results of the conducted experiment allow to conclude that highly efficient denitrification of nitrates is feasible in the reactor with a biofilm working in $12 \mathrm{~h}$ cycles upon the use of an external source of organic carbon. The $\mathrm{C}: \mathrm{N}$ ratio of 2 ensured the total nitrogen concentration in the effluent below $1 \mathrm{mgN} \cdot \mathrm{dm}^{-3}$. The increase of nitrates load fed to the reactor caused an increase in the dephosphatation activity of microorganisms. This may contribute to the reduced demand for organic carbon which is indispensable for the nitrogen and phosphorus removal. The reduced organic carbon requirement may affect the operating costs in a full scale wastewater treatment plant.

\section{Acknowledgments}

The project was funded by the National Science Centre allocated on the basis of the decision nr DEC-2012/07/N/ST8/03201

\section{REFERENCES}

1. Boltz J.P., Morgenroth E., Daigger G.T., DeBarbadillo C., Murthy S., Sørensen K.H., Stinson B. 2012. Method to identify potential phosphorus rate-limiting conditions in post-denitrification biofilm reactors within systems designed for simultaneous low-level effluent nitrogen and phosphorus concentrations. Water Res. 46, 6228-6238. doi:10.1016/j.watres.2012.08.020

2. Boltz J.P., Smets B.F., Rittmann B.E., Van Loosdrecht M.C.M., Morgenroth E., Daigger G.T. 2017. 
From biofilm ecology to reactors: A focused review. Water Sci. Technol. 75, 1753-1760. doi:10.2166/ wst.2017.061

3. Cydzik-Kwiatkowska A., Rusanowska P., Głowacka K. 2016. Operation mode and external carbon dose as determining factors in elemental composition and morphology of aerobic granules. Arch. Environ. Prot. 42, 74-79. doi:10.1515/aep2016-0009

4. Gieseke A., Arnz P., Amann R., Schramm A. 2002. Simultaneous $\mathrm{P}$ and $\mathrm{N}$ removal in a sequencing batch biofilm reactor: Insights from reactor- and microscale investigations. Water Res. 36, 501-509. doi:10.1016/S0043-1354(01)00232-9

5. Guo H., Zhou J., Jing W., Zhang X., Zhang Z., Uddin M.S. 2005. Performance and microbial structure of a combined biofilm reactor. Bioprocess Biosyst. Eng. 27, 249-254. doi:10.1007/s00449-005-0404-6

6. Helness H., Odegaard H. 2001. Biological phosphorus and nitrogen removal in a sequencing batch moving bed biofilm reactor. Water Sci. Technol. 43, 233-240.

7. Janczukowicz W., Rodziewicz J. 2013. Źródła węgla w procesach biologicznego usuwania związków azotu i fosforu, Monografia. ed. Komitet Inżynierii Środowiska Polska Akademia Nauk, Lublin. (in Polish)

8. Jena J., Kumar R., Saifuddin M., Dixit A., Das T. 2016. Anoxic-aerobic SBR system for nitrate, phosphate and COD removal from high-strength wastewater and diversity study of microbial communities. Biochem. Eng. J. 105, 80-89. doi:10.1016/j. bej.2015.09.007

9. Mieczkowski D., Cydzik-Kwiatkowska A., Rusanowska P., Świątczak P. 2016. Temperature-induced changes in treatment efficiency and microbial structure of aerobic granules treating landfill leachate. World J. Microbiol. Biotechnol. 32, 91. doi:10.1007/s11274-016-2046-Z

10. Mielcarek A., Janczukowicz W., Ostrowska K., Jóźwiak T., Klodowska I., Rodziewicz J., Zieliński
M. 2013. Biodegradability evaluation of wastewaters from malt and beer production. J. Inst. Brew. 119, 242-250. doi:10.1002/jib.92

11. Mielcarek A., Rodziewicz J., Janczukowicz W., Dabrowska D., Ciesielski S., Thornton A., StrukSokołowska J. 2017. Citric acid application for denitrification process support in biofilm reactor. Chemosphere 171, 512-519. doi:10.1016/j.chemosphere.2016.12.099

12. Mielcarek A., Rodziewicz J., Janczukowicz W., Dulski T., Ciesielski S., Thornton A. 2016. Denitrification aided by waste beer in anaerobic sequencing batch biofilm reactor (AnSBBR). Ecol. Eng. 95, 384-389. doi:10.1016/j.ecoleng.2016.06.083

13. Nerenberg R. 2016. The membrane-biofilm reactor (MBfR) as a counter-diffusional biofilm process. Curr. Opin. Biotechnol. doi:10.1016/j.copbio.2016.01.015

14. Nicolella C., van Loosdrecht M.C.M., Heijnen J.J. 2000a. Wastewater treatment with particulate biofilm reactors. J. Biotechnol. 80, 1-33. doi:10.1016/ S0168-1656(00)00229-7

15. Nicolella C., van Loosdrecht M.C.M., Heijnen J.J. 2000b. Wastewater treatment with particulate biofilm reactors. J. Biotechnol. doi:10.1016/ S0168-1656(00)00229-7

16. Park J.B.K., Craggs R.J., Sukias J.P.S. 2008. Treatment of hydroponic wastewater by denitrification filters using plant prunings as the organic carbon source. Bioresour. Technol. 99, 2711-2716. doi:10.1016/j.biortech.2007.07.009

17. Swinarski M., Makinia J., Czerwionka K., Chrzanowska M., Drewnowski J. 2009. Comparison of the effects of conventional and alternative external carbon sources on enhancing the denitrification process. Water Environ. Res. 81, 896-906. doi:10.2175/106143009X407438

18. Zeng R.J., Yuan Z., Keller J. 2003. Enrichment of denitrifying glycogen-accumulating organisms in anaerobic/anoxic activated sludge system. Biotechnol. Bioeng. 81, 397-404. doi:10.1002/bit.10484 